\title{
Review
}

Journal of Innate

Immunity
J Innate Immun 2012;4:349-360

DOI: $\underline{10.1159 / 000336844}$
Received: December 21, 2011

Accepted after revision: January 25, 2012

Published online: March 27, 2012

\section{The Multiple Facets of Dermcidin in Cell Survival and Host Defense}

\author{
Birgit Schittek \\ Department of Dermatology, University of Tübingen, Tübingen, Germany
}

\author{
Key Words \\ Antimicrobial peptides $\cdot$ Dermcidin $\cdot$ Host defense $\cdot$ Skin \\ innate immune response
}

\begin{abstract}
Eccrine sweat glands, which are distributed over the whole bodies of primates and humans, have long been regarded mainly to have a function in thermoregulation. However, the discovery of dermcidin-derived antimicrobial peptides in eccrine sweat demonstrated that sweat actively participates in the constitutive innate immune defense of human skin against infection. In the meantime, a number of studies proved the importance of dermcidin in skin host defense. Several reports also state that peptides processed from the dermcidin precursor protein exhibit a range of other biological functions in neuronal and cancer cells. This review summarizes the evidence gathered until now concerning the expression of dermcidin and the functional relevance of dermcidin-derived peptides.

Copyright $\odot 2012$ S. Karger AG, Basel
\end{abstract}

\section{Introduction}

Ten years ago our group discovered dermcidin, a gene expressed in human eccrine sweat glands. Its precursor protein is secreted into sweat, where it is proteolytically processed to give rise to antimicrobial peptides (AMPs) with a broad spectrum of activity under sweat-like conditions $[1-3]$. Owing to their persistence and abundance, dermcidin-derived peptides contribute to the first line of skin defense by building a constant barrier that overlies the epithelium. Especially at body sites most likely to come into contact with pathogenic microorganisms, such as the face and hands, a large amount of antimicrobially active dermcidin peptides was detected in sweat [4]. Dermcidin is the most abundant AMP found in this body fluid. Other AMPs, such as LL-37 and proteolytic derivatives of LL-37, were detected in human eccrine sweat, however at concentrations about 20 times too low to exert antimicrobial activity $[4,5]$. Just recently, another AMP, the iron-binding glycoprotein lactoferrin, was found in human eccrine sweat but at low concentrations as well [6].

\section{Evolution of Eccrine Sweat Glands}

During evolution, sweat glands developed only in mammals. Sweating is the most effective evaporative heat loss mechanism in humans, and humans have the highest number of eccrine sweat glands among mammals [7, 8]. Apocrine sweat glands are directly connected to the hair structure and are found in humans in the pubic and anal regions and in the axilla. Humans have the lowest density of apocrine glands among all primate species. Their secretion is associated with the release of smell and is not used for thermoregulation. Apocrine glands most likely

\section{KARGER \\ Fax +41613061234 \\ E-Mail karger@karger.ch}

www.karger.com (c) 2012 S. Karger AG, Basel

$1662-811 \mathrm{X} / 12 / 0044-0349 \$ 38.00 / 0$

Accessible online at:

www.karger.com/jin
Prof. Dr. Birgit Schittek

Department of Dermatology, Eberhard Karl's University

Liebermeisterstrasse 25

DE-72076 Tübingen (Germany)

Tel. +4970712980832, E-Mail birgit.schittek@med.uni-tuebingen.de 
Fig. 1. a Genomic organization of the human dermcidin gene. $\mathbf{b}$ Protein sequence of the dermcidin precursor protein as well as its division into functional domains (c). The precursor protein consists of a 19-amino-acid signal peptide (underlined), a 43-amino-acid prodomain and a 48-amino-acid AMP domain (in italics in the sequence).

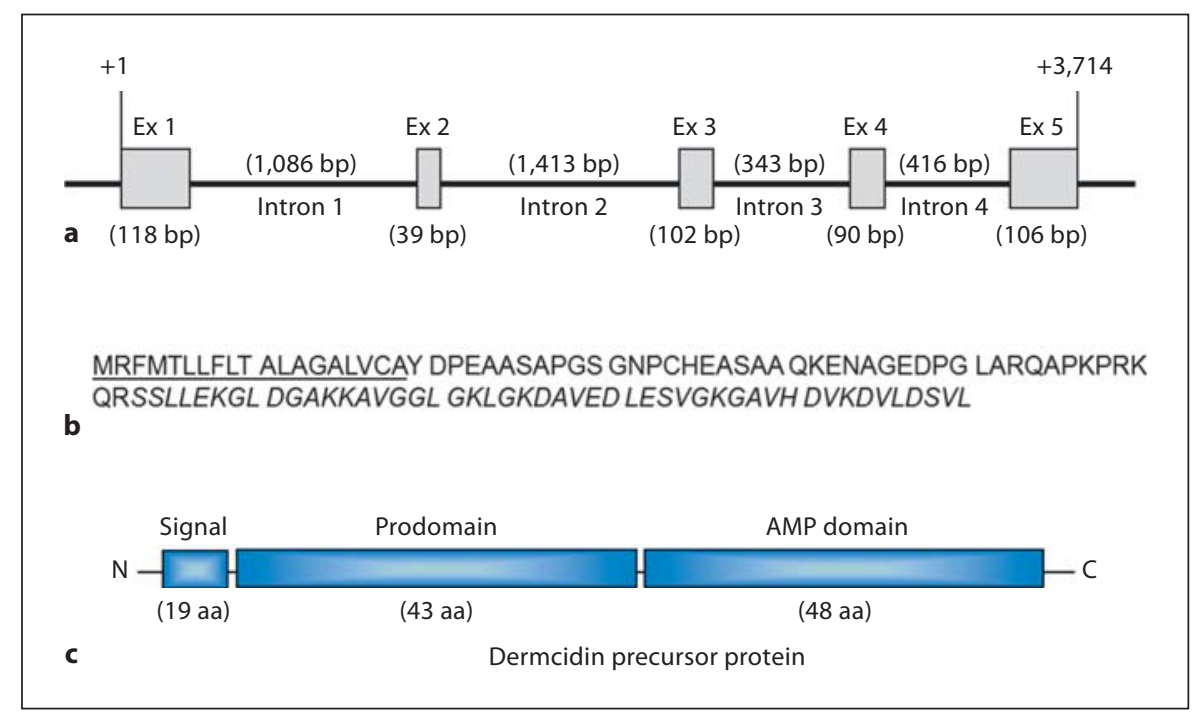

function as territorial marking or are part of an alarm reaction, whereas eccrine sweat glands have a heat control function $[9,10]$.

Other mammals, such as horses and cattle, have mostly apocrine sweat glands. Rodents have few eccrine sweat glands at their footpads; however, they do not use them for thermoregulation. Primates have both apocrine and eccrine sweat glands, and use eccrine sweat to control body temperature [11]. Whereas prosimians and monkeys have eccrine sweat glands mainly on the hands, feet and tail, in great apes - our direct ancestors - they are distributed over the whole body [7]. Therefore, it seems that the disappearance of hairs from the face and body during evolution has been accompanied by the spread of eccrine glands and a decrease in the number of apocrine glands. However, although the loss of body hairs is linked to the loss of apocrine glands, the spread of eccrine sweat glands over the body is not directly connected to hair loss as seen in great apes.

\section{Organization of the Dermcidin Gene and Protein}

The human dermcidin gene is located on chromosome 12q13.1 at location 53.324,699-53.328,544. The region spans approximately $3.7 \mathrm{~kb}$ in the genome [3] (http:// www.germonline.org/Homo_sapiens/geneview?gene= ENSG00000161634). The gene consists of 5 exons and 4 introns and codes for a 458-bp mature DCD RNA with an open reading frame of $330 \mathrm{bp}$ (fig. 1a) [3]. Prediction analyses by FGENES or Genescan as well as expression analyses confirm the existence of only one dermcidin transcript with no splice variants [3, 12-16]. However, one group found two alternative dermcidin splice variants with additional intronic sequences, which were found to be present in human term placenta [17].

Mature dermcidin RNA codes for a precursor protein with 110 amino acid residues and a molecular weight of $11.2 \mathrm{kDa}$ (fig. 1b). The first 19 amino acids encode a signal peptide, indicating that dermcidin is a secreted protein with a molecular weight of $9.5 \mathrm{kDa}$ and an isolelectric point of 5.8. The secreted precursor protein can be subdivided in a prodomain and an AMP domain (fig. 1c). One potential serine phosphorylation site can be found at amino acid position 64. There is no typical N-glycosylation site (Asn-X-Ser/Thr) in the dermcidin amino acid sequence, but there is one atypical $\mathrm{N}$-glycosylation site at amino acid position 32. Net-O-Glyc modeling did not reveal any Ser/Thr sites meeting the threshold for O-glycosylation $[3,15,18,19]$.

\section{Homologous Dermcidin Genes in Humans and Other Species}

Dermcidin has no significant homology to other known human genes or proteins. It has recently been suggested that the dermcidin gene is generated by gene duplication of the lacritin gene, which is located on chromosome 12, adjacent to the dermcidin gene [20]. Lacritin is specifically expressed in the lacrimal gland and is secreted into tears, where it might act as an eye-specific growth 

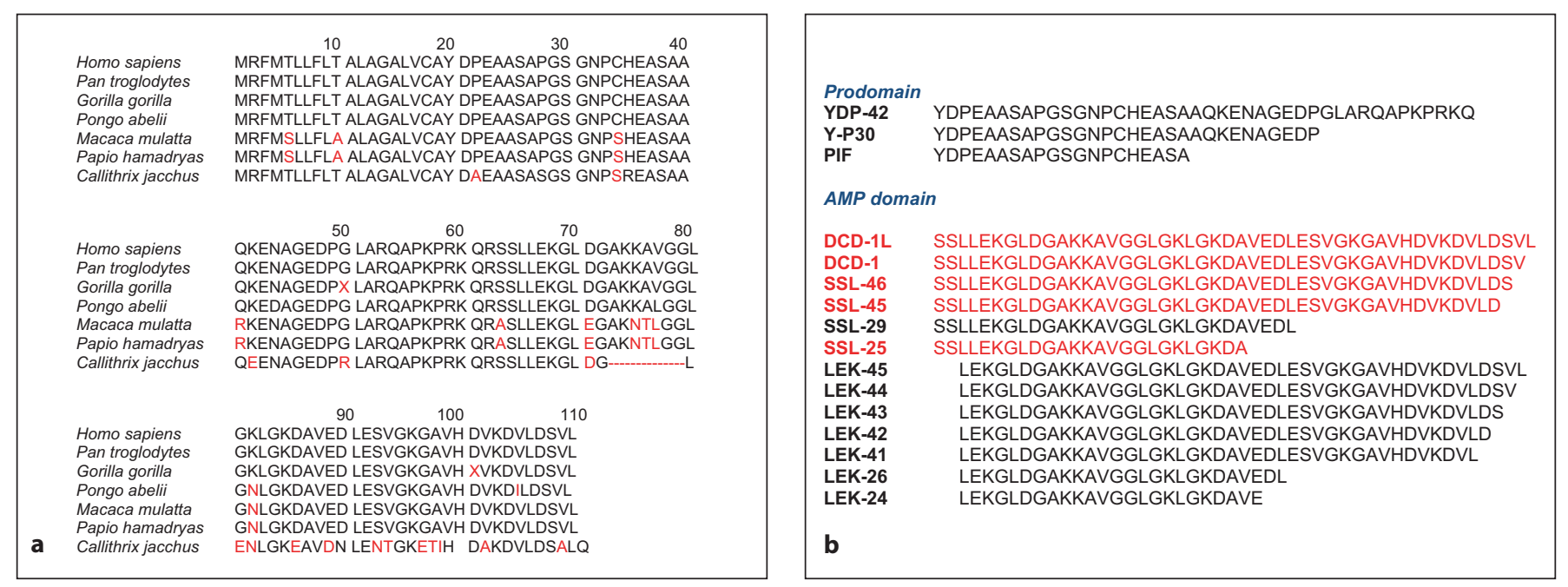

Fig. 2. a Alignment of the protein sequences of human dermcidin with homologous dermcidin protein sequences of different primates. Differences are shown in red. b Processed peptides identified from the different domains of the dermcidin precursor protein. Antimicrobially active peptides are marked in red.

factor $[21,22]$. There are striking similarities between lacritin and dermcidin in that the two genes have a similar exonic structure and are both expressed in a secretory gland. However, the sequence similarity is very weak and is mainly restricted to the signal peptide sequence rather than the functional regions, suggesting that dermcidin is not a paralog gene of lacritin [20,21].

Do dermcidin-homologous genes exist in other species? The complete genome sequence and predicted proteins of a number of species, including microbes, arthropods and vertebrates, are available in different databases, e.g. http://genome.cse.ucsc.edu. The sequence information together with new database features now enables us to find unambiguously orthologous genes in other species and to delineate evolution of genes. The dermcidin gene evolved late since homologous genes are only found in primates. Significant homology at the protein level is found in great apes, such as chimpanzees (Pan troglodytes), gorillas (Gorilla gorilla) and orangutans (Pongo abelii), in Old World monkeys, such as macaques (Macaca mulatta) and baboons (Papio hamadryas), as well as in the New World monkey Callithrix jacchus (fig. 2a). The sequence similiarity at protein level is amazingly high and reaches $100 \%$ in the great apes and is lowest in the New World monkey. There are no homologous genes in other less related primates such as in tarsiers, mouse lemurs and bushbabies (http://genome.cse.ucsc.edu). Furthermore, other vertebrates, such as wallabies, cats, dogs, horses or rodents, do not have dermcidin homologous genes [23]. Based on these facts, it is very astonishing that several publications claim that dermcidin is expressed in mice [19, 24-32], rats [33] and the tammar wallaby [34]. In summary, since dermcidin homologous genes are only found in primates, one can conclude that dermcidin is an orphan gene. Interestingly, it seems that the evolution of thermoregulatory sweating in humans and primates correlates with the gain of the dermcidin gene and dermcidin gene expression.

\section{Processing of the Dermcidin Precursor Protein}

The dermcidin precursor protein has a high susceptibility for proteolytic processing [3, 4, 35]. After cleavage of the 19-amino-acid N-terminal signal peptide and secretion into sweat, the 91-amino-acid dermcidin precursor protein can undergo further proteolytic processing. In eccrine sweat, 14 proteolytically processed dermcidin-derived peptides are found, 1 peptide derived from the prodomain named YDP-42 and 13 peptides derived from the AMP domain (fig. 2b). The temporal order of postsecretory processing of the peptides derived from the AMP domain in sweat has been elucidated as well as the proteases involved $[4,36,37]$. It starts with the 48 -aminoacid peptide DCD-1L, from which the C-terminal leucine is rapidly split off by a 1,10-phenanthroline-sensitive carboxypeptidase. It is still an open question which protease cleaves the dermcidin precursor protein at the QRSSL an- 
gle to generate DCD-1L. Further processing of DCD-1 by endoproteases, carboxypeptidases and cathepsin D generates shortened dermcidin-derived peptides lacking either the first 3 amino acids SSL and/or C-terminal amino acids [36]. The peptides are named according to their length and the identity of the first 3 amino acids in the peptide, i.e. LEK-45 or SSL-25 (fig. 2b). Processing of DCD-1L is individually different, but generates a few dominant peptides, with most individuals having 7-9 Cterminal dermcidin-derived peptides in their sweat [4]. The processed peptides are very stable in sweat and can survive up to 11 weeks at room temperature $[4,38]$. This is in contradiction with a publication which suggests that an in vitro-generated recombinant dermcidin precursor protein itself has a proteolytic activity [17]. However, the observed trypsin-like proteolytic activity might be derived from the copurified recombinant enterokinases needed for the cleavage of the N-terminal tag.

Further dermcidin products have been mentioned to be processed by neuronal cells or tumor cells. A peptide comprising the first 30 amino acids of the dermcidin precursor protein was named Y-P30 or diffusible survival evasion peptide (DSEP) [31] (fig. 2b). Another peptide mentioned to be processed by tumor cells is the proteolysis-inducing factor (PIF), also named cachexia-associated protein (HCAP) (fig. 2b). PIF is a 20 -amino-acid protein derived from the N-terminal end of the dermcidin protein and is thus a shortened version of the Y-P30 peptide [19].

\section{Expression Profile of Dermcidin in Humans}

\section{Eccrine Sweat Glands}

Several groups reported that dermcidin has a very restricted expression pattern and is not expressed at RNA level in several human adult and fetal tissues except in skin $[3,19,39]$. In human skin, dermcidin is expressed in the dark mucous cells of the secretory coil of eccrine sweat glands and is found in the Golgi complex and the secretory granules typical for a secreted protein $[3,4]$. Many other groups confirmed this finding and dermcidin is indisputably a very abundant protein in human eccrine sweat [19, 38, 40-42]. Dermcidin is secreted into sweat at a constant rate and the precursor peptide is rapidly processed to smaller peptides [4]. Most likely because of the extreme stability of dermcidin in sweat [38] and the stickiness of the protein, it can still be isolated from forensic samples and from clothes such as undershirts and socks [42]. The amount of dermcidin-derived peptides in eccrine sweat varies from one individual to another, depends on the body site and is especially large on the face, palms and arms [4]. The total mean concentration of dermcidin-derived peptides in sweat derived from the forehead is approximately $70 \mu \mathrm{g} / \mathrm{ml}$ [43]. The concentration of DCD-1 in sweat taken from the face, neck or chest ranges between 1 and $20 \mu \mathrm{g} / \mathrm{ml}$ with an average of $10 \mu \mathrm{g} /$ $\mathrm{ml}[3,37]$.

Dermcidin cannot be isolated from apocrine sweat and is not expressed in apocrine sweat glands $[3,38]$. Furthermore, in contrast to the inducible $\beta$-defensins, dermcidin expression is not induced under inflammatory conditions in keratinocytes [38, 41,44]. Nor is dermcidin present in other body fluids, such as nasal secretions, tears, saliva, semen, milk and urine $[4,38,42,45]$. However, one recent study using a sensitive proteomic approach found dermcidin in basal tears [46]. Another study detected dermcidin in samples of cervicovaginal fluid by a proteomic approach [47]. However, dermcidin seems not to be an abundant protein in these body fluids.

\section{Neuronal Cells and Placenta}

Using a dot blot hybridization array, dermcidin RNA expression was detected by Porter et al. [39] in the pons and at a lower level in the paracentral gyrus in the brain. Other groups isolated the dermcidin-derived peptide Y-P30 from the medium of oxidatively stressed cell lines of nervous system origin as the human retinoblastoma cell line Y79 and the mouse hippocampal cell line HN33.1 $[30,31]$. One group found dermcidin RNA splice products in human term placental tissue [17]. Nevertheless, it remains to be clarified whether dermcidin is expressed at the protein level in parts of human brain or placenta.

\section{Peripheral Blood Leukocytes}

Analysis of peripheral blood leukocytes from healthy individuals did not provide evidence that dermcidin is expressed in these cells $[3,38,39,42]$. Later, Landgraf et al. [33] showed using RT-PCR that dermcidin RNA is expressed in the peripheral blood leukocytes of pregnant women up to week 29 of pregnancy. However, in the same study, the authors describe a rat dermcidin homologue which is $100 \%$ homologous to the human gene at protein level [33], indicating that contamination with human material is likely to have taken place in the expression analyses of cells of human and rat origin.

In another study, a 105-amino-acid, low-abundance protein homologous to an aggregate of several short dermcidin-derived peptides was isolated from the plasma of patients with acute myocardial infarction [48]. The cell 
types secreting these peptides into the plasma have not been identified in this study. Interestingly, using proteomic approaches, dermcidin peptide fragments were found in low abundance in human neutrophils [49]. This report suggests that dermcidin might be stored in the neutrophil granules and the protein released if the neutrophils are stimulated - similar to the release of defensins.

\section{Cancer Cells}

Minami et al. [40, 41] performed immunohistochemical studies on 197 cutaneous tumors with a monoclonal antibody to dermcidin. They found no expression in epithelial, follicular, melanocytic, neural, mesenchymal or sweat gland neoplasms except in 13 out of 26 mixed tumors of sweat gland neoplasms which could possibly differentiate into eccrine secretory glands.

However, there are several reports stating that dermcidin is expressed in a subset of cancer cells or cell lines. The first report came from Tisdale's group in 1996, describing a cancer cachectic factor expressed in the murine adenocarcinoma cell line MAC16 [25]. The group developed a monoclonal antibody against that factor and identified the product as the dermcidin-derived peptide PIF. Many studies followed, describing the presence of PIF in mouse and human cancer cell lines, such as the human melanoma cell line G361, and in the urine of cachectic cancer patients $[25,50,51]$. Further studies by this group provided evidence that PIF is present in weight-losing cancer patients with a variety of malignancies, including cancer of the pancreas, breast, ovary and lung $[12,14,24$, $28,29,51,52]$. However, neither the expression nor the functional studies could be reproduced by other groups $[15,16,19,53-55]$. One reason might be that most PIF expression studies are based on detection with the monoclonal antibody developed by Tisdale's group. In 2007, Wieland et al. [15] showed that this antibody binds unspecifically to albumin and immunoglobulin light chains and does not detect PIF. This result as well as the fact that (a) PIF has no typical glycosylation site and (b) mice do not have a dermcidin homologue raises some concerns about the studies performed with this monoclonal antibody.

Other studies reported that dermcidin is expressed in a subset of breast carcinomas. Porter et al. [39] found that dermcidin RNA is expressed in approximately $10 \%$ of invasive breast carcinomas, mostly due to a focal copy number gain of its locus at 12q13.1. There was intratumoral heterogeneity with only a subset of cells in the tumor expressing dermcidin at high levels. Interestingly, its ex- pression was associated with advanced clinical stage and poor prognosis. In two other reports, dermcidin RNA expression was seen in 3 breast tumors [16] and in approximately $20 \%$ of estrogen receptor-positive invasive ductal carcinomas [56].

Dermcidin expression was also found in other tumor types, such as hepatocellular carcinoma tumor tissue or cell lines [57], gastroesophageal tumors [12], pancreatic cancer cell lines [13] and in a myelogenous leukemic cell line [58]. Our own studies indicate that one can induce a low level of RNA, but not protein expression, in oxidatively stressed melanoma cells [44]. Interestingly, the human acute monocytic leukemia cell line THP-1 was found to express the dermcidin precursor protein after HIV infection [59]. Further studies should clarify whether dermcidin protein expression is found in subsets of cancer cells and in virus-infected leukocytes.

\section{Functional Role of Dermcidin-Derived Peptides}

Peptides processed from the dermcidin precursor protein exhibit a range of biological functions (table 1). Besides the well-described function of peptides derived from the AMP domain in host defense, dermcidin-derived peptides derived from the prodomain have been reported to exert a survival-promoting effect on neuronal cells and tumor cells (Y-P30), and to be a factor that induces muscle proteolysis, causing cancer cachexia (PIF). Furthermore, dermcidin itself has been reported to be a putative oncogene in cancer cells [19].

\section{Survival-Promoting Effect of Y-P30}

Y-P30 is an acid-stable, proteolysis-resistant factor present in medium conditioned by both nervous system cell lines and embryonic cortical neurons. Y-P30 was defined as a 'survival-promoting peptide' since gene expression was induced in these cells after oxidative stress and the processed peptide promotes survival of the retinoblastoma cells. Y-P30 binds IgG and demonstrates phosphatase activity, properties that are described to be important for its biological effects [30, 31, 60]. A survivalpromoting effect of Y-P30 was also described for the hepatocellular carcinoma cell line $\mathrm{HuH} 7[18,61]$ and the prostate cancer cell line PC-3M [62].

Administration of the Y-P30 peptide to rats showed that it is neuroprotective after optic nerve damage, but it does not stimulate axon outgrowth [63]. Y-P30 has no influence on proliferation and differentiation of neural progenitors, neurons and astrocytes [32], but promotes neu- 
Table 1. Overview about the evidence obtained until now concerning the expression of dermcidin in humans and the functional role of processed peptides

\begin{tabular}{|c|c|c|c|c|}
\hline Expression & Stimuli & Functional peptide(s) & Activity & References \\
\hline $\begin{array}{l}\text { Eccrine } \\
\text { sweat glands }\end{array}$ & $\begin{array}{l}\text { none, constitutive } \\
\text { expression }\end{array}$ & $\begin{array}{l}\text { DCD-1L, DCD-1, SSL-25, } \\
\text { SSL-23 }\end{array}$ & $\begin{array}{l}\text { antimicrobial, } \\
\text { skin defense, } \\
\text { inflammation }\end{array}$ & $\begin{array}{l}3,4,37,38,41-44 \\
72-78,80,81,85\end{array}$ \\
\hline $\begin{array}{l}\text { Subtypes of } \\
\text { neuronal cells }\end{array}$ & oxidative stress & Y-P30 & $\begin{array}{l}\text { survival-promoting, } \\
\text { promigratory }\end{array}$ & $\begin{array}{l}30-32,39,57,58,60, \\
63,64\end{array}$ \\
\hline PBLs, neutrophils & viral infection, PMA & $\mathrm{ND}$ & ND & $33,48,49$ \\
\hline Term placenta & none & Y-P30, others? & ND & 17 \\
\hline
\end{tabular}

$\mathrm{PBL}=$ Peripheral blood lymphocyte; ND = not determined.

rite outgrowth from thalamic and cerebellar neurons [64]. Landgraf et al. [64] identified pleiotropin and syndecan-2/3 as Y-P30 receptors. Another Y-P30 target on cell membranes, calreticulin, a ubiquitous calcium-binding protein that is critical for integrin function, was identified as well [60].

A region in the Y-P30 sequence (GNPCH) was recently found to bind to the heat shock protein HSP70 in an ATP-dependent manner [58]. Stocki et al. [58] have shown that a region of the Y-P30 peptide which partially overlaps the HSP70 binding site (CHEASAAQK) binds to HLA-A*03 [58]. This interaction stabilizes Y-P30 and protects the peptide from further degradation; these two important functions shed some light on how Y-P30 fulfills its prosurvival action. Indeed, substitution of glutamine for asparagine at position $32(\mathrm{GNPCH}$ to GQPCH), which is localized at the HSP70 recognition site, abrogates the prosurvival action of Y-P30 [18]. Another actor, Nck1, was also recently found [57]. It was shown that Nck1 binds to a phosphotyrosine residue at position 20 in the Y-P30 sequence. In conclusion, Y-P30 has been described by several groups to have a prosurvival action on stressed neuronal cells and the mechanism has been partially elucidated. The physiological relevance of these findings with respect to the in vivo presence of this peptide in the brain remains to be clarified.

\section{Cancer Cachexia Induced by PIF}

Todorov et al. [25] consider PIF as a mediator of cancer-associated weight loss. PIF induces skeletal muscle proteolysis in vitro and in vivo by depressing protein syn- thesis and by increasing protein degradation [51, 65-69]. The peptide core of this $4-\mathrm{kDa}$ peptide is sulfated and glycosylated, thus contributing to an estimated size of 24 $\mathrm{kDa}$ [68]. The glycosylation of PIF is essential for its proteolytic activity as neither the peptide core alone nor the deglycosylated native PIF has any effect on weight loss in mice $[19,25]$. Further studies provided evidence that PIF is present in the urine of weight-losing cancer patients with a variety of malignancies, including cancer of the pancreas, breast, ovary and lung $[12,14,24,28,29,51,52]$. However, PIF represents only $5 \times 10^{-4} \%$ of the total urinary proteins [51]. When PIF is administered to animals, it induces weight loss, activation of the ubiquitin-proteasome system in skeletal muscles and activation of NF- $\mathrm{KB}$ $[51,65,68,70]$. However, Jatoi et al. [55] could not find any correlation between the presence of PIF and weight loss or between its presence and anorexia in metastatic gastric/esophageal cancer patients. Nor was there evidence that the presence of PIF in urine is able to predict tumor response or survival in these patients or in patients with pancreatic tumors [54]. In another study, it was shown that PIF stimulates the production of IL- 6 and IL- 8 and the acute-phase protein C-reactive protein $(\mathrm{CRP})$ in hepatocytes via induction of NF- $\mathrm{KB}$ and Stat3 [67]. In endothelial cell types, PIF also seems to induce the shedding of syndecans from the cell surface. Syndecans are involved in wound repair, cancer metastasis and embryonic development [67].

It was recently suggested that a PIF receptor, which is a DING-type protein, is present on mouse skeletal muscle cells. Mirza et al. [29] found that an N-terminal peptide of 
Table 2. Spectrum of antimicrobial activity of dermcidin-derived peptides

\begin{tabular}{lcll}
\hline Microorganism & $\begin{array}{l}\text { DCD-1/DCD-1L } \\
\mathrm{IC}_{90}, \mu \mathrm{g} / \mathrm{ml}\end{array}$ & $\begin{array}{l}\text { SSL-25 } \\
\mathrm{IC}_{90}, \mu \mathrm{g} / \mathrm{ml}\end{array}$ & References \\
\hline S. aureus (MSSA) & $9-45$ & $9-48$ & $72-75,77,81$ \\
S. aureus (MRSA) & 8 & 35 & 77 \\
S. epidermidis & $10-50$ & 6 & 76,77 \\
E. coli & $45-84$ & 10 & $73,75,77$ \\
P. aeruginosa & $95-200$ & $15-200$ & 77,81 \\
C. albicans & $10-477$ & $\mathrm{ND}$ & $3,73,75$ \\
S. typhimurium & 68 & $\mathrm{ND}$ & 75 \\
L. monocytogenes & 108 & $\mathrm{ND}$ & 75 \\
P. sputida & $0.5\left(\mathrm{IC}_{50}\right)$ & $\mathrm{ND}$ & 73 \\
\hline
\end{tabular}

Inhibitory concentrations that kill $90 \%$ of the indicated microorganisms $\left(\mathrm{IC}_{90}\right)$. MSSA = Methicillin-sensitive S. aureus; MRSA = methicillin-resistant $S$. aureus ND = not determined.

the PIF receptor attenuated muscle atrophy. However, although PIF attenuated protein degradation in vitro, in vivo studies showed that PIF does not significantly attenuate weight loss in mice. In contrast, another study showed that injection of dermcidin into mice by adenoviral gene transfer led to decreased body weight and increased body fat mobilization by activation of adipocyte lipolysis. These effects are most likely mediated by PIF [71].

In conclusion, PIF seems to induce muscle proteolysis and contribute to cachexia observed in some cancer patients, although these results have been questioned by other groups. However, the identity of the product identified as PIF has still to be proven as PIF expression is found in mice and the only available antibody to detect PIF detects IgG and albumin rather than PIF [15].

\section{Oncogene in Cancer Cells}

It was reported that dermcidin is expressed in approximately $10 \%$ of invasive breast carcinomas, mostly due to a focal copy number gain of its locus at 12q13.1 and that its expression is associated with advanced clinical stage and poor prognosis in breast cancer [39]. Dermcidin expression in tumor cells promotes cell growth and survival and reduces serum dependency. It was suggested that high- and low-affinity receptors for dermcidin are present on the cell surface of breast carcinomas and mediate the effect.

Motoyama et al. [17] suggested that $5 \mu \mathrm{g}$ of recombinant mature dermcidin increases invasion of a choriocarcinoma cell line in vitro; this effect can be inhibited by phenanthroline, an inhibitor of metalloproteinases. Fur-

Dermcidin in Cell Survival and Host Defense thermore, it was shown that overexpression of dermcidin in a hepatocarcinoma cell line promoted migration by activation of $\rho$-GTPases [57]. Likewise, Dash-Wagh et al. [32] found that Y-P30 enhanced migration of T24 human bladder carcinoma cells and rat primary cortical astrocytes. In summary, most studies studying the effects of dermcidin expression in cancer cells postulate that ectopic dermcidin expression results in enhanced proliferation, survival and migration of cancer cells. However, it remains to be tested whether dermcidin is expressed in these cells at protein level and further processed and whether the observed functional effects can be ascribed to a specific proteolytic product of the dermcidin precursor protein.

\section{Skin Host Defense}

Several groups confirmed that peptides derived from the AMP domain of the dermcidin precursor protein have a broad-spectrum activity against several types of microbes, but have no hemolytic activity $[3,72-76]$. The most abundant DCD peptides in sweat that are antimicrobially active are the anionic DCD-1L and DCD-1 and the cationic SSL-25 and SSL-23 (fig. 2b). Interestingly, these peptides have a diverse and overlapping spectrum of activity that is independent of the net peptide charge $[72,77]$ (table 2). These peptides show antimicrobial activity against pathogenic microorganisms such as Staphylococcus aureus, Escherichia coli, Enterococcus faecalis and Candida albicans under in vitro conditions resembling human sweat. Further investigations by our group and others revealed an extended antimicrobial spectrum including Staphylococcus epidermidis, Pseudomonas aeruginosa, Pseudomonas putida, methicillin-resistant S. aureus, Listeria monocytogenes and Salmonella typhimurium [73, 75, 76]. Interestingly, several workers were able to express recombinant dermcidin in bacteria and purify antimicrobially active DCD-1 or DCD-1L [73, $75,78]$. These peptides, however, have mostly lower activities than synthesized peptides, probably due to the presence of additional amino acids in the peptide sequence due to the cleavage of a tag. Investigations into the mechanism of antimicrobial activity indicated that, irrespective of their net charge, DCD peptides interact with bacterial membrane phospholipids and kill Gram-negative bacteria without forming large pores in bacterial membranes $[72,77]$. Remarkably and untypically for an AMP, the antimicrobial activity of DCD-1L is maintained over a broad $\mathrm{pH}$ range and at high salt concentrations that resemble the conditions in human sweat $[3,73$, 76]. This remarkable activity as well as the fact that DCD- 


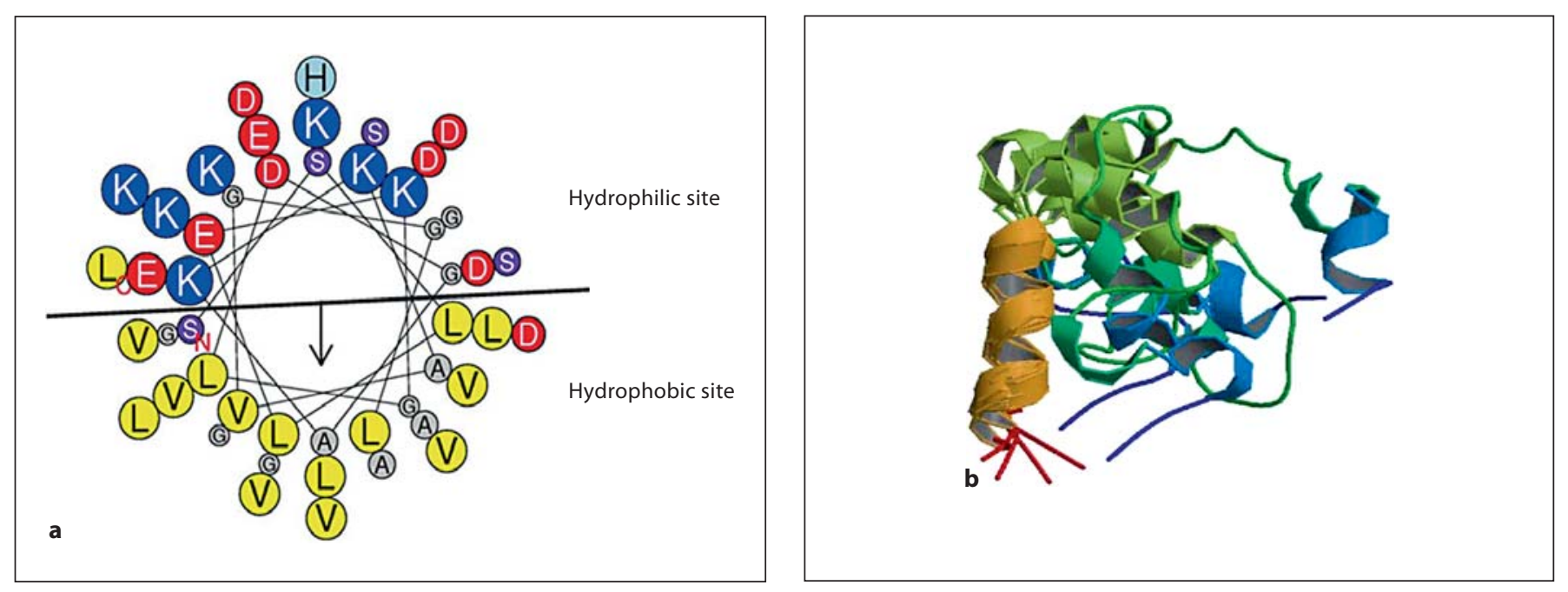

Fig. 3. a Helical wheel plot of DCD-1L. Prediction of the secondary structure by the Chou-Fasman algorithm of DCD-1L based on the amino acid sequence. There are three potential $\alpha$-helical regions (a.a. 1-14, a.a. 26-32, a.a. 36-45). The helical wheel plot (http://heliquest.ipmc.cnrs.fr/ cgi-bin/ComputParams.py) indicates a partitioning into a hydrophilic and a hydrophobic face, as typical for amphiphilic peptides. b NMR secondary structure of DCD-1L in 50\% TFE is shown (taken from http://www.rcsb.org/pdb/explore.do? structureId=2ksg; see also Jung et al. [79]). c Schematic view of human skin with the different epidermal layers and an eccrine sweat gland secreting sweat (brown dots at the skin surface). Commensal bacteria such as $S$. epidermidis (shown in green) can survive on skin. Pathogens such as $S$. aureus (shown in blue) are killed by the action of different antimicrobially active substances secreted by skin-derived cells. This protects human skin from invading pathogens.

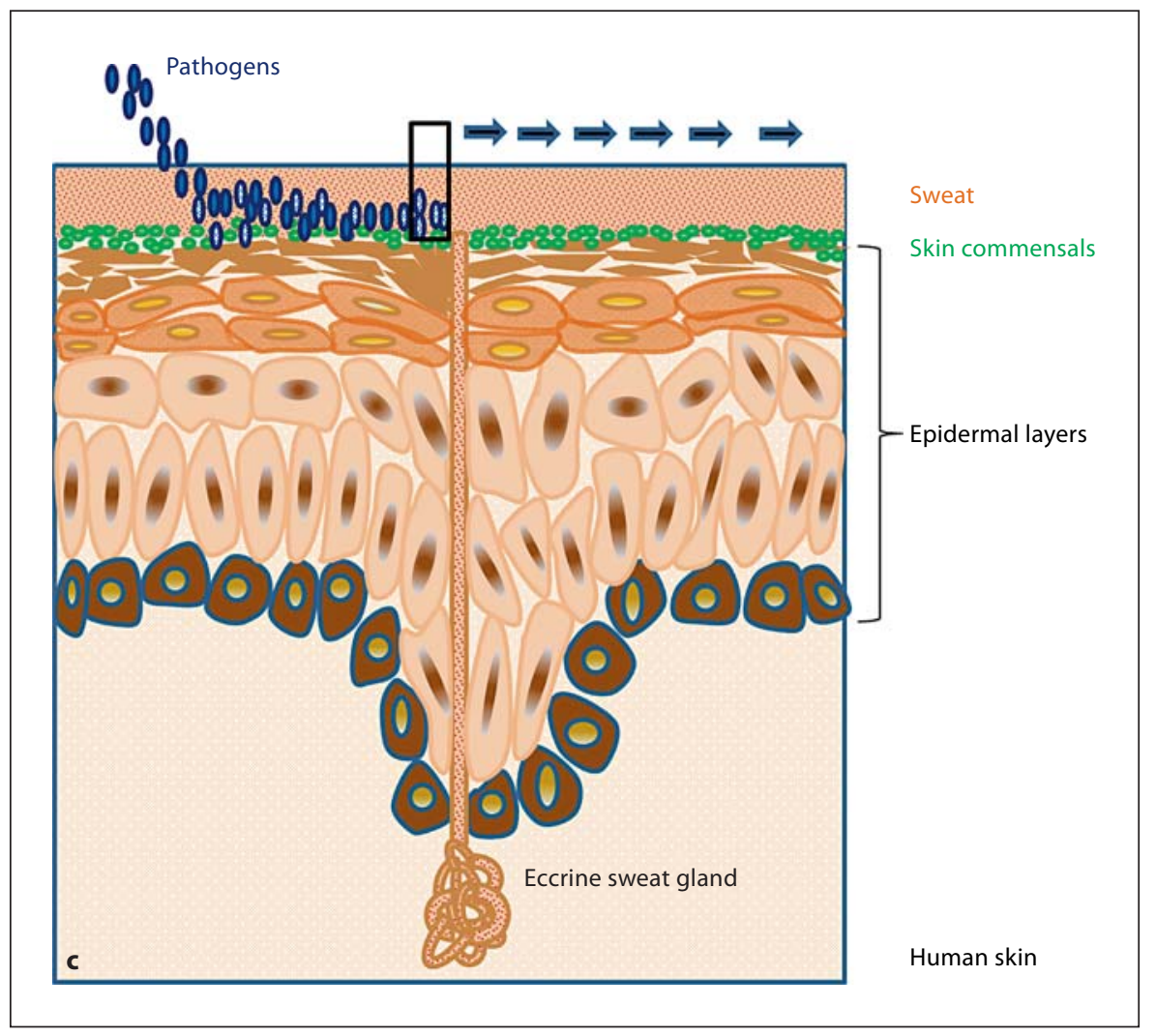

$1 \mathrm{~L}$ is anionic in contrast to most other AMPs suggested that the functional mechanism of DCD-1L might be different from most other AMPs.

DCD-1L is amphipathic in that the charged residues cluster on one side of the helix, while the hydrophobic residues cluster on the other side (fig. 3a). DCD-1L easily self-associates to form higher-order oligomers and has an anomalous electrophoretic mobility in the presence of SDS molecules $[35,77]$. Solution-NMR analyses in 50\% TFE indicate that the DCD-1L topology consists of four $\alpha$-helices and is highly flexible, especially the $\mathrm{N}$-terminus of DCD-1L (amino acid position 1-23) [79] (fig. 3b). This could facilitate DCD-1L binding to bacterial membrane phospholipids [74]. Indeed, we recently showed that 


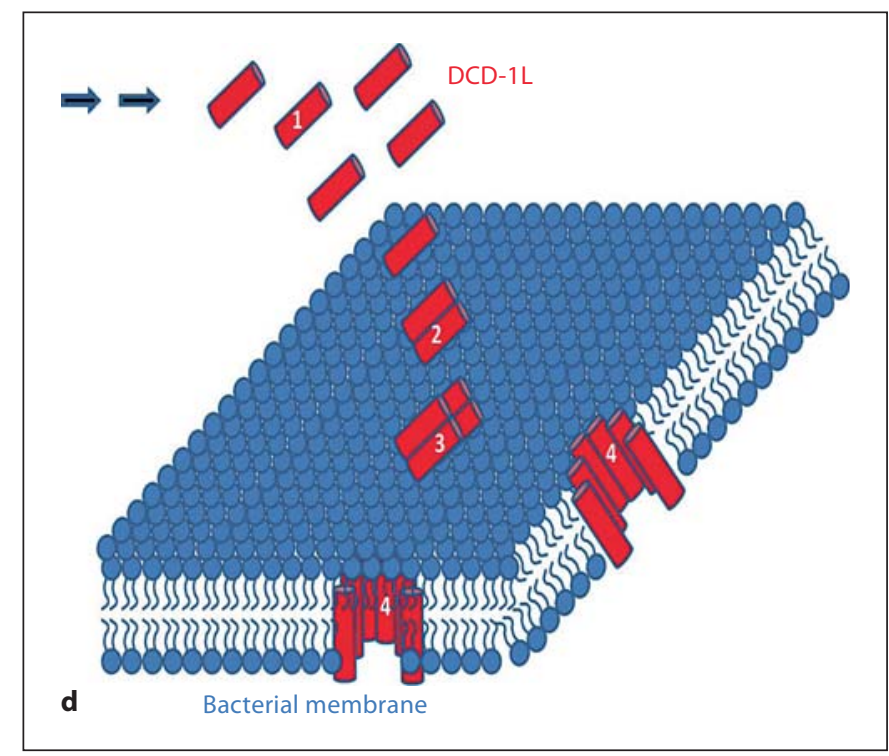

Fig. 3. The framed section is shown in $\mathbf{d}$ indicating the proposed action of DCD-1L on the bacterial membrane. DCD-1L is first monomeric in human sweat (1). As soon as DCD-1L binds to bacterial membrane phospholipids, it oligomerizes $(2,3)$ and forms ion channels in the bacterial membrane (4), resulting in bacterial death.

DCD-1L interacts preferentially with negatively charged bacterial phospholipids with a helix axis that is aligned flat on a lipid bilayer surface [80]. Upon interaction with lipid bilayers, DCD-1L forms oligomeric complexes that are stabilized by $\mathrm{Zn}^{2+}$ and forms ion channels in the bacterial membrane. Therefore, we propose that $\mathrm{Zn}^{2}$-induced self-assembly of DCD-1L upon interaction with bacterial lipid bilayers is a prerequisite for ion channel formation and bacterial killing (fig. 3c, d) [80]. DCD-1L seems to be ideally adapted to the acidic and salty conditions in human sweat to fulfill its role in host defense. Furthermore, dermcidin might have evolved mechanisms to evade proteolytic degradation by bacterial proteases in a hostile environment like sweat, replete with host-derived proteases. We demonstrated that bacterial proteases from $S$. aureus and $P$. aeruginosa showed limited proteolytic activity against dermcidin-derived peptides under physiological conditions [81], which was, however, questioned by another group [82]. One protection mechanism might be the ability of DCD-1L to oligomerize, and thus decrease protease sensitivity.

Continually secreted sweat-derived dermcidin contributes to the constitutive innate defense of human skin by modulating surface colonization rather than respond- ing to injury and inflammation as observed with the inducible peptides HBD-2 and -3 or human cathelicidin LL37. Dermcidin may thus help to prevent local and systemic invasion of pathogens. The question still remains how skin commensals as S. epidermidis resist the innate host defense. It has been shown that polysaccharide intercellular adhesin (PIA), which is mainly expressed by bacteria growing in a biofilm, protects $S$. epidermidis against DCD-1L under sweat-like conditions, i.e. low $\mathrm{pH}$ and high salt concentrations [76]. Furthermore, it has been elegantly demonstrated that $S$. epidermidis senses AMPs by a three-component sensor/regulator system which upregulates resistance mechanisms to cationic AMPs in order to coordinate a targeted defensive response [83]. Interestingly, DCD-1L does not activate this AMP-sensing system due to its negative net charge [84]. Further studies should clarify why $S$. epidermidis can survive on human skin, although dermcidin-derived peptides are constantly present (fig. 3c).

The clinical relevance of dermcidin was shown by a study which indicates that patients with atopic dermatitis have a reduced amount of dermcidin-derived AMPs in their sweat, which correlate with an impaired innate defense of human skin in vivo [43]. These data suggest that the reduced presence of dermcidin-derived peptides in patients with atopic dermatitis contributes to the high susceptibility of these patients to skin infections and altered skin colonization.

Finally, Niyonsaba et al. [85] reported that dermcidinderived peptides exert other functions too in host defense. They showed that DCD-1 and DCD-1L activate normal human keratinocytes by inducing the proinflammatory cytokines TNF- $\alpha$, IL-8 (CXCL8), interferon-inducible protein 10 (CXCL10) and macrophage inflammatory protein-3 $\alpha$ (CCL20). Cytokine induction and chemokine production are controlled by G-protein and MAPK pathways and result in activation of the NF- $\kappa B$ signaling pathway, and p38 and ERK. This interesting study indicates that dermcidin participates in the regulation of skin innate immunity not only by direct bacterial killing, but also by regulation of skin inflammation.

\section{Conclusion}

The purpose of this review was to shed light on the evidence and viewpoints obtained until now concerning the expression and functional relevance of dermcidin and the peptides derived from it. A number of controversial issues about dermcidin expression and function have 
been published. There is no doubt that dermcidin is highly expressed in human eccrine sweat glands and secreted into sweat. Proteolytic processing of dermcidin in sweat yields several dermcidin-derived AMPs which play a role in the constitutive innate defense of human skin. Other reports describing low or moderate expression levels in subsets of cancer cells or peripheral blood leukocytes need to be validated at protein level and the processed peptides have to be identified. Dermcidin expression may be induced in cancer cells following a focal copy number gain of the dermcidin locus at 12q13. If dermcidin protein expression can indeed be found in cancer cells or other cell types than sweat glands, it would be interesting to analyze the functional relevance of the expressed protein or processed peptides. Furthermore, it is important to identify the cell type expressing the protein product, especially when working with tissues that may have contaminated skin (with eccrine sweat glands) fragments in the preparation, which might be the case when taking breast tissue. The fact that dermcidin is a very abundant and stable protein in human sweat and hence on human skin may also be a source of problems. It is very sticky and can be isolated from forensic samples and from clothes, such as undershirts and socks. One should carefully check the expression data, especially when using highly sensitive PCR or proteomics techniques. Dermcidin has no homologue in rodents or other mammals except for primates which shows that dermcidin is an orphan gene. The finding of dermcidin RNA or protein in species lacking the dermcidin gene indicate that cross-contamination with human materials is likely to have occurred. Interestingly, the evolution of eccrine sweat glands as a thermoregulatory organ and its distribution over the whole body correlate with the gain of the dermcidin gene, which might be advantageous to increase skin host defense. Furthermore, the published data suggest that dermcidin might have several functions in host defense, cell survival, cancer cachexia and carcinogenesis. While there is clear evidence concerning the role of dermcidin in host defense, its role in cell survival and carcinogenesis and its physiological significance have still to be elucidated. There is still a lot to do to unravel the expression and functional relevance of peptides derived from this fascinating molecule.

\section{Acknowledgment}

This work was supported by the Deutsche Forschungsgemeinschaft (SFB766).

\section{References}

1 Schittek B, Paulmann M, Senyurek I, Steffen $\mathrm{H}$ : The role of antimicrobial peptides in human skin and in skin infectious diseases. Infect Disord Drug Targets 2008;8:135-143.

2 Wiesner J, Vilcinskas A: Antimicrobial peptides: the ancient arm of the human immune system. Virulence 2010;1:440-464.

3 Schittek B, Hipfel R, Sauer B, Bauer J, Kalbacher H, Stevanovic S, Schirle M, Schroeder K, Blin N, Meier F, Rassner G, Garbe C: Dermcidin: a novel human antibiotic peptide secreted by sweat glands. Nat Immunol 2001;2:1133-1137.

4 Rieg S, Seeber S, Steffen H, Humeny A, Kalbacher H, Stevanovic S, Kimura A, Garbe C, Schittek B: Generation of multiple stable dermcidin-derived antimicrobial peptides in sweat of different body sites. J Invest Dermatol 2006; 126:354-365.

5 Murakami M, Ohtake T, Dorschner RA, Schittek B, Garbe C, Gallo RL: Cathelicidin anti-microbial peptide expression in sweat, an innate defense system for the skin. J Invest Dermatol 2002;119:1090-1095.
6 Park JH, Park GT, Cho IH, Sim SM, Yang JM, Lee DY: An antimicrobial protein, lactoferrin exists in the sweat: proteomic analysis of sweat. Exp Dermatol 2011;20:369-371.

7 Folk GE Jr, Semken HA Jr: The evolution of sweat glands. Int J Biometeorol 1991;35:180186.

8 Wilke K, Martin A, Terstegen L, Biel SS: A short history of sweat gland biology. Int J Cosmet Sci 2007;29:169-179.

9 Lupi O: Paleodermatology. Int J Dermatol 2008;47:9-12.

10 Lupi O: Ancient adaptations of human skin: why do we retain sebaceous and apocrine glands? Int J Dermatol 2008;47:651-654.

11 Elizondo RS: Primate models to study eccrine sweating. Am J Primatol 1988:265-276.

12 Deans DA, Wigmore SJ, Gilmour H, Tisdale MJ, Fearon KC, Ross JA: Expression of the proteolysis-inducing factor core peptide mRNA is upregulated in both tumour and adjacent normal tissue in gastro-oesophageal malignancy. Br J Cancer 2006;94:731736.
3 Stewart GD, Skipworth RJ, Pennington CJ, Lowrie AG, Deans DA, Edwards DR, Habib FK, Riddick AC, Fearon KC, Ross JA: Variation in dermcidin expression in a range of primary human tumours and in hypoxic/ oxidatively stressed human cell lines. $\mathrm{Br} \mathrm{J}$ Cancer 2008;99:126-132.

14 Wang Z, Corey E, Hass GM, Higano CS, True LD, Wallace D Jr, Tisdale MJ, Vessella RL: Expression of the human cachexia-associated protein (HCAP) in prostate cancer and in a prostate cancer animal model of cachexia. Int J Cancer 2003;105:123-129.

15 Wieland BM, Stewart GD, Skipworth RJ, Sangster K, Fearon KC, Ross JA, Reiman TJ, Easaw J, Mourtzakis M, Kumar V, Pak BJ, Calder K, Filippatos G, Kremastinos DT, Palcic M, Baracos VE: Is there a human homologue to the murine proteolysis-inducing factor? Clin Cancer Res 2007;13:4984-4992.

$\checkmark 16$ Monitto CL, Dong SM, Jen J, Sidransky D: Characterization of a human homologue of proteolysis-inducing factor and its role in cancer cachexia. Clin Cancer Res 2004;10: 5862-5869. 
17 Lee Motoyama JP, Kim-Motoyama H, Kim P, Nakagama H, Miyagawa K, Suzuki K: Identification of dermcidin in human gestational tissue and characterization of its proteolytic activity. Biochem Biophys Res Commun 2007;357:828-833.

-18 Lowrie AG, Wigmore SJ, Wright DJ, Waddell ID, Ross JA: Dermcidin expression in hepatic cells improves survival without $\mathrm{N}$-glycosylation, but requires asparagine residues. Br J Cancer 2006;94:1663-1671.

-19 Stewart GD, Skipworth RJ, Ross JA, Fearon $\mathrm{KC}, \mathrm{Baracos} \mathrm{VE}$ : The dermcidin gene in cancer: role in cachexia, carcinogenesis and tumour cell survival. Curr Opin Clin Nutr Metab Care 2008;11:208-213.

20 Toll-Riera M, Laurie S, Rado-Trilla N, Mar Alba M: Partial gene duplication and the formation of novel genes; in Friedberg F (ed): Gene Duplication. InTech 2011, pp 95-110.

-21 McKown RL, Wang N, Raab RW, Karnati R, Zhang Y, Williams PB, Laurie GW: Lacritin and other new proteins of the lacrimal functional unit. Exp Eye Res 2009;88:848-858.

-22 Ma P, Wang N, McKown RL, Raab RW, Laurie GW: Focus on molecules: lacritin. Exp Eye Res 2008;86:457-458.

23 Waterhouse RM, Zdobnov EM, Tegenfeldt F, Li J, Kriventseva EV: OrthoDB: the hierarchical catalog of eukaryotic orthologs in 2011. Nucleic Acids Res 2011;39:D283-D288.

24 McDevitt TM, Todorov PT, Beck SA, Khan SH, Tisdale MJ: Purification and characterization of a lipid-mobilizing factor associated with cachexia-inducing tumors in mice and humans. Cancer Res 1995;55:1458-1463.

-25 Todorov P, Cariuk P, McDevitt T, Coles B, Fearon K, Tisdale M: Characterization of a cancer cachectic factor. Nature 1996;379: 739-742.

-26 Todorov PT, McDevitt TM, Cariuk P, Coles B, Deacon M, Tisdale MJ: Induction of muscle protein degradation and weight loss by a tumor product. Cancer Res 1996;56:12561261.

-27 Todorov PT, Wyke SM, Tisdale MJ: Identification and characterization of a membrane receptor for proteolysis-inducing factor on skeletal muscle. Cancer Res 2007;67:1141911427.

28 Hussey HJ, Todorov PT, Field WN, Inagaki $\mathrm{N}$, Tanaka Y, Ishitsuka H, Tisdale MJ: Effect of a fluorinated pyrimidine on cachexia and tumour growth in murine cachexia models: relationship with a proteolysis inducing factor. Br J Cancer 2000;83:56-62.

29 Mirza KA, Wyke SM, Tisdale MJ: Attenuation of muscle atrophy by an N-terminal peptide of the receptor for proteolysis-inducing factor (PIF). Br J Cancer 2011;105:83-88

30 Cunningham TJ, Jing H, Akerblom I, Morgan R, Fisher TS, Neveu M: Identification of the human cDNA for new survival/evasion peptide (DSEP): studies in vitro and in vivo of overexpression by neural cells. Exp Neurol 2002;177:32-39.
Cunningham TJ, Hodge L, Speicher D, Reim D, Tyler-Polsz C, Levitt P, Eagleson K, Kennedy S, Wang Y: Identification of a survivalpromoting peptide in medium conditioned by oxidatively stressed cell lines of nervous system origin. J Neurosci 1998;18:70477060.

32 Dash-Wagh S, Neumann JR, Veitinger S, Grote-Westrick C, Landgraf P, Pape HC, Kreutz MR, von HA, Wahle P: The survival promoting peptide Y-P30 promotes cellular migration. Mol Cell Neurosci 2011;48:195204.

33 Landgraf P, Sieg F, Wahle P, Meyer G, Kreutz MR, Pape HC: A maternal blood-borne factor promotes survival of the developing thalamus. FASEB J 2005; 19:225-227.

34 Ambatipudi K, Deane EM: In search of neutrophil granule proteins of the tammar wallaby (Macropus eugenii). Mol Immunol 2008; 45:690-700.

35 Majczak G, Lilla S, Garay-Malpartida M, Markovic J, Medrano FJ, de NG, Belizario JE: Prediction and biochemical characterization of intrinsic disorder in the structure of proteolysis-inducing factor/dermcidin. Genet Mol Res 2007;6:1000-1011.

36 Baechle D, Flad T, Cansier A, Steffen H, Schittek B, Tolson J, Herrmann T, Dihazi H, Beck A, Mueller GA, Mueller M, Stevanovic S, Garbe C, Mueller CA, Kalbacher H: Cathepsin $\mathrm{D}$ is present in human eccrine sweat and involved in the postsecretory processing of the antimicrobial peptide DCD-1L. J Biol Chem 2006;281:5406-5415.

- 37 Flad T, Bogumil R, Tolson J, Schittek B, Garbe C, Deeg M, Mueller CA, Kalbacher H: Detection of dermcidin-derived peptides in sweat by ProteinChip technology. J Immunol Methods 2002;270:53-62.

38 Sagawa K, Kimura A, Saito Y, Inoue H, Yasuda S, Nosaka M, Tsuji T: Production and characterization of a monoclonal antibody for sweat-specific protein and its application for sweat identification. Int J Legal Med 2003;117:90-95.

39 Porter D, Weremowicz S, Chin K, Seth P, Keshaviah A, Lahti-Domenici J, Bae YK, Monitto CL, Merlos-Suarez A, Chan J, Hulette CM, Richardson A, Morton CC, Marks J, Duyao M, Hruban R, Gabrielson E, Gelman R, Polyak K: A neural survival factor is a candidate oncogene in breast cancer. Proc Natl Acad Sci USA 2003;100:10931-10936.

$\checkmark 40$ Minami Y, Uede K, Furukawa F, Sagawa K, Kimura A, Tsuji T: Cutaneous mixed tumors: an immunohistochemical study using two antibodies, G-81 and C8/144B. J Dermatol Sci 2004;36:180-182.

41 Minami Y, Uede K, Sagawa K, Kimura A, Tsuji T, Furukawa F: Immunohistochemical staining of cutaneous tumours with G-81, a monoclonal antibody to dermcidin. Br J Dermatol 2004;151:165-169.
42 Sakurada K, Akutsu T, Fukushima H, Watanabe K, Yoshino M: Detection of dermcidin for sweat identification by real-time RT-PCR and ELISA. Forensic Sci Int 2010;194:80-84.

43 Rieg S, Steffen H, Seeber S, Humeny A, Kalbacher H, Dietz K, Garbe C, Schittek B: Deficiency of dermcidin-derived antimicrobial peptides in sweat of patients with atopic dermatitis correlates with an impaired innate defense of human skin in vivo. J Immunol 2005;174:8003-8010.

44 Rieg S, Garbe C, Sauer B, Kalbacher H, Schittek B: Dermcidin is constitutively produced by eccrine sweat glands and is not induced in epidermal cells under inflammatory skin conditions. Br J Dermatol 2004;151:534-539.

-45 McIntosh RS, Cade JE, Al-Abed M, Shanmuganathan V, Gupta R, Bhan A, Tighe PJ, Dua HS: The spectrum of antimicrobial peptide expression at the ocular surface. Invest Ophthalmol Vis Sci 2005;46:1379-1385.

46 You J, Fitzgerald A, Cozzi PJ, Zhao Z, Graham P, Russell PJ, Walsh BJ, Willcox M, Zhong L, Wasinger V, Li Y: Post-translation modification of proteins in tears. Electrophoresis 2010;31:1853-1861.

47 Shaw JL, Smith CR, Diamandis EP: Proteomic analysis of human cervico-vaginal fluid. J Proteome Res 2007;6:2859-2865.

48 Ghosh R, Karmohapatra SK, Bhattacharyya M, Bhattacharya R, Bhattacharya G, Sinha AK: The appearance of dermcidin isoform 2, a novel platelet aggregating agent in the circulation in acute myocardial infarction that inhibits insulin synthesis and the restoration by acetyl salicylic acid of its effects. J Thromb Thrombolysis 2011;31:13-21.

-49 Lominadze G, Powell DW, Luerman GC, Link AJ, Ward RA, McLeish KR: Proteomic analysis of human neutrophil granules. Mol Cell Proteomics 2005;4:1503-1521.

50 Todorov PT, Field WN, Tisdale MJ: Role of a proteolysis-inducing factor (PIF) in cachexia induced by a human melanoma (G361). Br J Cancer 1999;80:1734-1737.

51 Cariuk P, Lorite MJ, Todorov PT, Field WN, Wigmore SJ, Tisdale MJ: Induction of cachexia in mice by a product isolated from the urine of cachectic cancer patients. Br J Cancer 1997;76:606-613.

52 Wigmore SJ, Todorov PT, Barber MD, Ross JA, Tisdale MJ, Fearon KC: Characteristics of patients with pancreatic cancer expressing a novel cancer cachectic factor. Br J Surg 2000; 87:53-58.

53 Cabal-Manzano R, Bhargava P, TorresDuarte A, Marshall J, Bhargava P, Wainer IW: Proteolysis-inducing factor is expressed in tumours of patients with gastrointestinal cancers and correlates with weight loss. Br J Cancer 2001;84:1599-1601.

54 Teich N, Kleeff J, Lochs H, Mossner J, Keim V, Friess H, Ockenga J: The presence of the proteolysis-inducing factor in urine does not predict the malignancy of a pancreatic tumour. BMC Gastroenterol 2005;5:20. 
55 Jatoi A, Foster N, Wieland B, Murphy B, Nikcevich D, LaPlant B, Palcic MM, Baracos $\mathrm{V}$ : The proteolysis-inducing factor: in search of its clinical relevance in patients with metastatic gastric/esophageal cancer. Dis Esophagus 2006;19:241-247.

56 Helms MW, Packeisen J, August C, Schittek B, Boecker W, Brandt BH, Buerger H: First evidence supporting a potential role for the BMP/SMAD pathway in the progression of oestrogen receptor-positive breast cancer. J Pathol 2005;206:366-376.

57 Shen SL, Qiu FH, Dayarathna TK, Wu J, Kuang M, Li SS, Peng BG, Nie J: Identification of dermcidin as a novel binding protein of Nck1 and characterization of its role in promoting cell migration. Biochim Biophys Acta 2011;1812:703-710.

-58 Stocki P, Wang XN, Morris NJ, Dickinson AM: HSP70 natively and specifically associates with an $\mathrm{N}$-terminal dermcidin-derived peptide that contains an HLA- $A^{*} 03$ antigenic epitope. J Biol Chem 2011;286:1280312811.

59 Pathak S, De Souza GA, Salte T, Wiker HG, Asjo B: HIV induces both a down-regulation of IRAK-4 that impairs TLR signalling and an up-regulation of the antibiotic peptide dermcidin in monocytic cells. Scand J Immunol 2009;70:264-276.

-60 Cunningham TJ, Jing H, Wang Y, Hodge L: Calreticulin binding and other biological activities of survival peptide Y-P30 including effects of systemic treatment of rats. Exp Neurol 2000;163:457-468.

61 Lowrie AG, Dickinson P, Wheelhouse N, Stewart GD, Ross AJ, Forster T, Ross JA: Proteolysis-inducing factor core peptide mediates dermcidin-induced proliferation of hepatic cells through multiple signalling networks. Int J Oncol 2011;39:709-718.

-62 Stewart GD, Lowrie AG, Riddick AC, Fearon KC, Habib FK, Ross JA: Dermcidin expression confers a survival advantage in prostate cancer cells subjected to oxidative stress or hypoxia. Prostate 2007;67:1308-1317.

63 Macharadze T, Landgraf P, Pape HC, Wahle P, Kreutz MR: Y-P30 confers neuroprotection after optic nerve crush in adult rats. Neuroreport 2011;22:544-547.

64 Landgraf P, Wahle P, Pape HC, Gundelfinger ED, Kreutz MR: The survival-promoting peptide Y-P30 enhances binding of pleiotrophin to syndecan-2 and -3 and supports its neuritogenic activity. J Biol Chem 2008;283: 25036-25045.
65 Lorite MJ, Smith HJ, Arnold JA, Morris A, Thompson MG, Tisdale MJ: Activation of ATP-ubiquitin-dependent proteolysis in skeletal muscle in vivo and murine myoblasts in vitro by a proteolysis-inducing factor (PIF). Br J Cancer 2001;85:297-302.

66 Lorite MJ, Thompson MG, Drake JL, Carling G, Tisdale MJ: Mechanism of muscle protein degradation induced by a cancer cachectic factor. Br J Cancer 1998;78:850-856.

67 Watchorn TM, Waddell I, Dowidar N, Ross JA: Proteolysis-inducing factor regulates hepatic gene expression via the transcription factors NF- $\kappa$ B and STAT3. FASEB J 2001;15: 562-564.

68 Todorov PT, Deacon M, Tisdale MJ: Structural analysis of a tumor-produced sulfated glycoprotein capable of initiating muscle protein degradation. J Biol Chem 1997;272: 12279-12288.

69 Lorite MJ, Cariuk P, Tisdale MJ: Induction of muscle protein degradation by a tumour factor. Br J Cancer 1997;76:1035-1040.

-70 Whitehouse AS, Tisdale MJ: Increased expression of the ubiquitin-proteasome pathway in murine myotubes by proteolysis-in ducing factor (PIF) is associated with activation of the transcription factor NF- $\kappa \mathrm{B}$. Br J Cancer 2003;89:1116-1122.

-71 Kim KA, Ka SO, Moon WS, Yi HK, Lee YH, Kwon KB, Park JW, Park BH: Effect of dermcidin, an antimicrobial peptide, on body fat mobilization in normal mice. J Endocrinol 2008;198:111-118.

72 Senyurek I, Paulmann M, Sinnberg T, Kalbacher H, Deeg M, Gutsmann T, Hermes M, Kohler T, Gotz F, Wolz C, Peschel A, Schittek B: Dermcidin-derived peptides show a different mode of action than the cathelicidin LL-37 against Staphylococcus aureus. Antimicrob Agents Chemother 2009;53:24992509.

73 Lai YP, Peng YF, Zuo Y, Li J, Huang J, Wang LF, Wu ZR: Functional and structural characterization of recombinant dermcidin-1L, a human antimicrobial peptide. Biochem Biophys Res Commun 2005;328:243-250.

74 Li M, Rigby K, Lai Y, Nair V, Peschel A, Schittek B, Otto M: Staphylococcus aureus mutant screen reveals interaction of the human antimicrobial peptide dermcidin with membrane phospholipids. Antimicrob Agents Chemother 2009;53:4200-4210.

75 Cipakova I, Gasperik J, Hostinova E: Expression and purification of human antimicrobial peptide, dermcidin, in Escherichia coli. Protein Expr Purif 2006;45:269-274.
76 Vuong C, Voyich JM, Fischer ER, Braughton KR, Whitney AR, DeLeo FR, Otto M: Polysaccharide intercellular adhesin (PIA) protects Staphylococcus epidermidis against major components of the human innate immune system. Cell Microbiol 2004;6: 269-275.

77 Steffen H, Rieg S, Wiedemann I, Kalbacher H, Deeg M, Sahl HG, Peschel A, Gotz F, Garbe C, Schittek B: Naturally processed dermcidin-derived peptides do not permeabilize bacterial membranes and kill microorganisms irrespective of their charge. Antimicrob Agents Chemother 2006;50:26082620.

78 Hong I, Kim YS, Choi SG: Simple purification of human antimicrobial peptide dermcidin (MDCD-1L) by intein-mediated expression in E. coli. J Microbiol Biotechnol 2010;20:350-355.

79 Jung HH, Yang ST, Sim JY, Lee S, Lee JY, Kim HH, Shin SY, Kim JI: Analysis of the solution structure of the human antibiotic peptide dermcidin and its interaction with phospholipid vesicles. BMB Rep 2010;43:362-368.

80 Paulmann M, Arnold T, Linke D, Ozdirekcan S, Kopp A, Gutsmann T, Kalbacher H, Wanke I, Schuenemann VJ, Habeck M, Burck J, Ulrich AS, Schittek B: Structure-activity analysis of the dermcidin-derived peptide DCD 1L, an anionic antimicrobial peptide present in human sweat. J Biol Chem 2012;287:8434-8443.

81 Senyurek I, Doring G, Kalbacher H, Deeg M, Peschel A, Wolz C, Schittek B: Resistance to dermcidin-derived peptides is independent of bacterial protease activity. Int J Antimicrob Agents 2009;34:86-90.

82 Lai Y, Villaruz AE, Li M, Cha DJ, Sturdevant DE, Otto M: The human anionic antimicrobial peptide dermcidin induces proteolytic defence mechanisms in staphylococci. Mol Microbiol 2007;63:497-506.

83 Li M, Lai Y, Villaruz AE, Cha DJ, Sturdevant DE, Otto M: Gram-positive three-component antimicrobial peptide-sensing system. Proc Natl Acad Sci USA 2007;104:94699474.

84 Li M, Cha DJ, Lai Y, Villaruz AE, Sturdevant DE, Otto M: The antimicrobial peptidesensing system APS of Staphylococcus aureus. Mol Microbiol 2007;66:1136-1147.

85 Niyonsaba F, Suzuki A, Ushio H, Nagaoka I, Ogawa H, Okumura K: The human antimicrobial peptide dermcidin activates normal human keratinocytes. Br J Dermatol 2009; 160:243-249. 